\title{
MIR127 wt Allele
}

National Cancer Institute

\section{Source}

National Cancer Institute. MIR127 wt Allele. NCI Thesaurus. Code C82072.

The human MIR127 wild-type allele is located in the vicinity of 14q32.31 and is approximately 96 bases in length. This allele, which encodes MIR127 pre-miRNA, plays a role in the regulation of gene expression. Alteration in the expression of this gene is associated with the development of cancers of the liver, colon, bladder, breast and prostate. 